\title{
Genetic Variation and Genotype by Environment Interaction for Heat Tolerance in Crisphead Lettuce
}

\author{
Abbas Lafta \\ Department of Plant Pathology, North Dakota State University, Fargo, ND \\ 58105
}

Germán Sandoya

Everglades Research and Education Center, University of Florida - IFAS, 3200 E. Palm Beach Road, Belle Glade, FL 33430

\section{Beiquan Mou} U.S. Department of Agriculture (USDA), Agricultural Research Service
(ARS), 1636 East Alisal Street, Salinas, CA 93905

Additional index words. bolting, GGE biplot, heat stress, Lactuca sativa, tipburn

\begin{abstract}
Lettuce (Lactuca sativa L.) is a cool season crop that is vulnerable to high temperature stress, which promotes bolting and decreases yield and quality. It is anticipated that climate change may lead to higher temperatures in current lettuce growing areas in the United States, thereby negatively affecting lettuce production and possibly resulting in adverse impacts on global food production. Therefore, it is important to identify lettuce germplasm with tolerance to temperatures higher than those that have occurred over the past century. We evaluated 25 crisphead lettuce cultivars for tolerance to high temperature stress in the San Joaquin, Imperial, and Salinas Valleys, CA. Genetic variation was identified for yield and horticultural traits, such as core length, head diameter, tipburn, bolting, and market maturity, of crisphead lettuce grown in warmer conditions. Significant genotype $\times$ environment interaction did not account for most of the variation; the main differences were found for environments and only a small proportion of the variation was due to genotypes. Cultivar Primetime is a good source of heat tolerance for crisphead lettuce, as it presented the best yield and exhibited other desirable characteristics across warmer conditions. These results provide insight into the cultivars that respond well to hot environments. Moreover, the data can be used by breeders to develop new heat-tolerant lettuce cultivars.
\end{abstract}

Lettuce (L. sativa L.) is a cool season crop that requires a daily average temperature of $18{ }^{\circ} \mathrm{C}$ for optimal development. Lettuce is planted year-round in temperate climates in many countries including the United States.

Received for publication 3 June 2020. Accepted for publication 31 July 2020.

Published online 18 December 2020.

We appreciate the technical assistance of Jeffrey Gunderson, Rafael Solorio, Dave Milligan, and Javier Mora. We thank James McCreight for his invaluable comments to improve the clarity of this manuscript. This research was supported by a grant from the California Department of Food and Agriculture's Specialty Crop Block Grant Program (SCB10042). G.S. acknowledges the hatch project FLA-EREC-005599.

The U.S. Department of Agriculture is an equal opportunity provider and employer. Mention of trade names or commercial products in this publication is solely for the purpose of providing specific information and does not imply recommendation or endorsement by the U.S. Department of Agriculture.

B.M. is the corresponding author. E-mail: beiquan. mou@usda.gov.

This is an open access article distributed under the CC BY-NC-ND license (https://creativecommons. org/licenses/by-nc-nd/4.0/).
China is the top producer in terms of area harvested $(648,738$ ha), followed by India (193,962 ha), the United States (117,032 ha), Italy (34,460 ha), Spain $(33,674$ ha), Turkey (22,576 ha), Japan (21,314 ha), and Mexico (20,527 ha) (FAOSTAT, 2018). The United States was the top producer in terms of harvested yield in 2018 with $31 \mathrm{t} /$ ha followed by Spain, Japan, China, Mexico, Italy, Turkey, and India, which produced 28, 27, $24,24,22,22$, and $6 \mathrm{t} / \mathrm{ha}$, respectively (FAOSTAT, 2018). Lettuce can be grown during the winter when temperatures are favorable in southern California, Arizona, and Florida. These three states account for $\approx 97 \%$ of the total area planted in the United States and have a farmgate value of $\approx \$ 3.5$ billion in the United States (USDA-NASS, 2019).

The average worldwide temperature is predicted to increase due to climate change over the next few decades and this increase in temperature will affect agricultural production (Karl and Trenberth, 2003; Wurr et al., 1996). Climate change is already threatening the leafy vegetable industry in Florida and potentially may affect western production areas, especially southern California and Arizona. Therefore, breeding lettuce culti- vars that tolerate warm temperatures is one of the priorities for leafy vegetable crops. The breeding process starts with screening available lettuce germplasm to identify lettuce cultivars that perform acceptably in warm conditions. Several leaf lettuce cultivars were identified to be heat tolerant in field conditions (Lafta et al., 2017). A few romaine cultivars performed well in greenhouses under warmer conditions (Holmes et al., 2019). Screening lettuce germplasm is particularly relevant for traits that are known to be affected by high temperature, such as physiological disorders like rib discoloration, tipburn, premature bolting, and ribbiness (Jenni, 2005; Jenni and Hayes, 2010; Jenni and Yan, 2009; Ryder, 1999). Rib discoloration is present in leaves as lettuce being exposed to warm conditions. This disorder is especially noticeable in older lettuce (Jenni and Yan, 2009). Tipburn is a physiological disorder associated with localized internal calcium deficiencies in lettuce (Barta and Tibbitts, 2000), which occurs during periods when rapid plant growth outpaces calcium transport (Barta and Tibbitts, 2000; Thibodeau and Minotti, 1969), and is more prominent in warm planting periods (Macias-González et al., 2019). Tipburn is especially detrimental to crisphead and romaine lettuce types, reducing the quality and shelf life of fresh and processed products. Many packing companies in the United States will reject entire fields of lettuce with a tipburn incidence greater than $5 \%$ because the symptoms are unacceptable to consumers and may lead to subsequent microbial rotting (Jenni and Hayes, 2010). Bolting is genetically controlled by several genes (Ryder and Milligan, 2005). The process is initiated by long photoperiods and high temperatures, and lettuce planted in warmer conditions tends to bolt faster (Silva et al., 1999). Early bolting shortens vegetative growth, resulting in reduced biomass. Once bolted, lettuce loses its marketability with poor head formation and bitter taste. Ribbiness is defined as protuberances of the outer ribs that prevents normal head development (Masarirambi et al., 2018), which is induced by high temperatures and long photoperiods (Jenni and Yan, 2009). These physiological disorders cause economic damage in all lettuce production areas (Barta and Tibbitts, 2000; Cox et al., 1976; Thibodeau and Minotti, 1969; Yanagi et al., 1983).

Yield of lettuce, especially in hot conditions, is controlled by genotype and environment but the influence by the interaction of both is still not well understood in crisphead (iceberg) lettuce. However, the yield of red and green leaf lettuce in hot conditions is controlled by this genotype $\times$ environment $(\mathrm{G}$ $\times$ E) interaction and must be considered during the breeding process (Lafta et al., 2017). Physiological disorders have an important $\mathrm{G} \times \mathrm{E}$ interaction that breeders must take into considerations when designing breeding strategies to improve heat tolerance in lettuce (Jenni and Hayes, 2010; Jenni and Yan, 2009). 
The genetic basis of heat tolerance of lettuce grown in field conditions has not been described in head lettuce, specifically crisphead cultivars, which account for $\approx 43 \%$ of the U.S. production (USDA-NASS, 2019). From the 1920s through the 1990s, crisphead lettuce dominated U.S. lettuce production, but its share of the market has steadily decreased over the past 30 years (Hayes, 2017). The yield of crisphead lettuce may decrease due to increasing temperatures in the current production areas. It is desirable to breed crisphead lettuce cultivars that develop uniform and marketable heads and do not bolt or present physiological disorders, such as tipburn, as consequence of excessive heat.

Therefore, the objectives of this study were to identify crisphead lettuce cultivars that tolerate high temperatures. To design a suitable breeding scheme for heat tolerance in lettuce, we investigated the cultivar $\times$ environment interactions that would maximize genetic gains in a breeding program. Our findings provide insight into the crisphead lettuce cultivars that respond well to hot environments. Moreover, these data can be used by breeders to develop new heattolerant lettuce cultivars.

\section{Materials and Methods}

Plant materials. Twenty-five crisphead lettuce cultivars (Table 1) were selected to test their responses to high temperature stress in five different environments based on their performances in preliminary growth chamber tests of more than 700 lettuce cultivars each with 163 -week-old seedlings exposed to
$43{ }^{\circ} \mathrm{C} 12 \mathrm{~h}$ day $/ 35{ }^{\circ} \mathrm{C} 12 \mathrm{~h}$ night, 450 $\mu \mathrm{mol} \cdot \mathrm{m}^{-2} \cdot \mathrm{s}^{-1}$ photosynthetic photon flux density for $7 \mathrm{~d}$, and then evaluated for leaf injury (rated on a $0-6$ scale: 0 , no injury; $1,<1 / 2$ leaf edge injured; $2,>1 / 2$ leaf edge injured; $3,<1 / 3$ leaf area injured; 4, $<2 / 3$ leaf area injured; $5,>2 / 3$ leaf area injured; 6 , plant dead), reduction in leaf fresh weight, and percent seedling survival compared with controls at $25^{\circ} \mathrm{C}$ day/ $17^{\circ} \mathrm{C}$ night (Lafta and Mou, unpublished data). Several of the cultivars were developed outside the United States (e.g., 'Reine des Glaces'). Controls were 'Salinas' and 'Vanguard 75', two cultivars well-adapted to the California central coast (Salinas Valley) and southwest United States (Imperial Valley, CA, and Yuma, AZ), respectively.

Experiments. Five field experiments were conducted in three different locations and different planting dates during 2012 and 2013. Two experiments were in the San Joaquin Valley at the University of California (UC) West Side Research and Extension Center (WSREC), Five Points, CA in Mar. 2013 and May 2012. Two experiments were planted in the Imperial Valley at the UC Desert Research and Extension Center (DREC), Holtville, CA, in Mar. 2013 and May 2012. One experiment was planted at the USDA-ARS, Salinas, CA, in June 2012. The experiments planted in March and May correspond with off-season plantings for southern production areas in California and Arizona. The June planting in Salinas, CA, corresponds with the summer in-season plantings in the Salinas Valley.

Each cultivar was direct-seeded in a 6-m long row in a $1-\mathrm{m}$ wide bed with two rows separated by $35 \mathrm{~cm}$. Plants were handthinned to be $30 \mathrm{~cm}$ apart in the row 3 weeks after planting. The experiments were maintained using standard practices for lettuce in the southern and central coast of California (Lafta et al., 2017). All experiments were arranged in a randomized complete block design with four replications.

Evaluation of crisphead quality. When controls ('Salinas' and 'Vanguard 75') reached market maturity, five plants of each cultivar were randomly harvested within a plot and evaluated for traits important to the crisphead lettuce industry. Yield was recorded on a plot basis and expressed as per head weight (HW) in grams. Core length (CL) was measured from the cut base to the apex of the head after splitting the lettuce head in half. These two measurements were then used for the ratio of $\mathrm{HW}$ to $\mathrm{CL}$ ( $\mathrm{g} / \mathrm{mm})$, an indicator of maturity and is related to head quality. Head diameter $(\mathrm{cm})$ was measured on the split heads at the widest side. Market maturity (firmness) was evaluated based on the following scale: 1 (soft or loose head); 2 (medium head filled); 3 (firm, good for the market); 4 (hard, past market maturity); and 5 (extra hard, over mature). Percentage bolted plants (\%) was estimated per plot by counting the number of plants that showed signs of bolting (significant stem elongation). Tipburn was assessed by counting the number of leaves per plant with visible tipburn damage.

Statistical analysis. Analysis of variance was done using JMP program (SAS Institute Inc., Cary, NC) to determine the effects of environment $(\mathrm{E})$, genotype $(\mathrm{G})$, and $\mathrm{G} \times \mathrm{E}$

Table 1. List of crisphead cultivars selected for heat tolerance trials from an initial screening of lettuce germplasm.

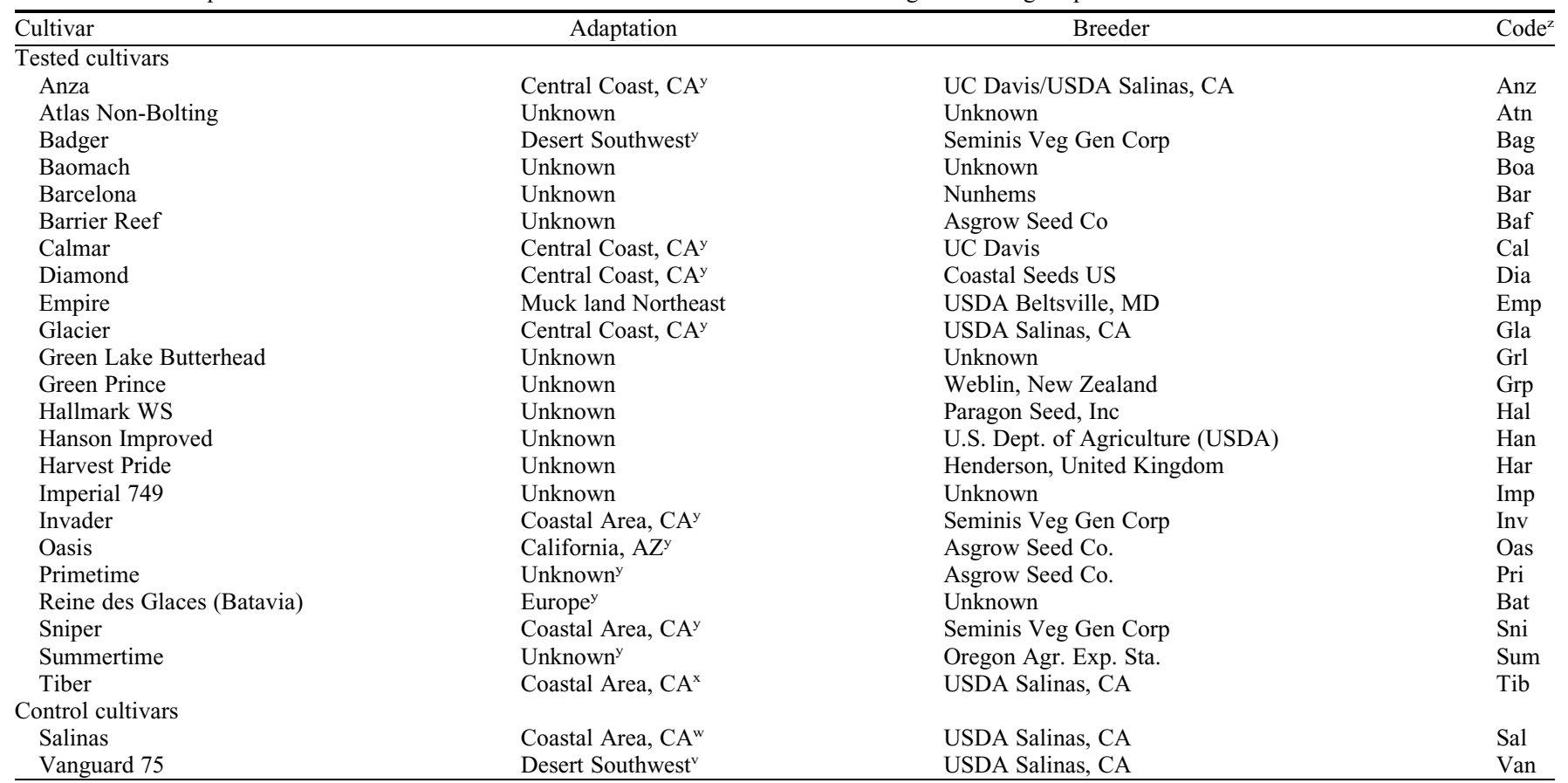

${ }^{\mathrm{z}}$ Code used for GGE biplot graph.

${ }^{\mathrm{y}}$ Ryder et al. (2016).

${ }^{\mathrm{x}}$ Ryder and Waycott (1998).

${ }^{\mathrm{w}}$ Ryder (1979a).

${ }^{\mathrm{v}}$ Ryder (1979b). 
interaction on crisphead HW and other characteristics, where environments were considered using the location-year combination. Genotypes were considered fixed effects; replicates nested in the environment, and environments were considered random effects. Treatment means were separated by Fisher's protected least significant difference test at $P=0.05$. A correlation analysis was also conducted to identify associations among the traits measured.

Analysis of genotype $+\mathrm{G} \times \mathrm{E}$ interaction (GGE) biplots (Yan and Kang, 2002; Yan et al., 2007) was conducted for all of the recorded traits. The biplot is based on the site regression linear-bilinear (multiplicative) model. For a full description of the equation, see Yan et al. (2007). Two analyses were performed on the recorded traits. The first analysis was the "which-won-where" method of the GGE biplot that was used to visualize the similarities among environments and to determine which cultivars are adequate for mega-environments. One megaenvironment can be defined as the representative environment in which a cultivar has the best performance. The second analysis was "mean vs. stability" of the GGE biplot because it facilitates genotype comparisons based on mean performance and stability across environments within a mega-environment (Yan et al., 2007). The GGE analysis was done using GGE biplot software (Yan, 2001).

\section{Results and Discussion}

The traits measured to determine heat tolerance in crisphead lettuce showed significant differences $(P<0.0001)$ among the tested cultivars (Table 2), indicating genetic variation for the traits under heat stress. These data confirmed a previous report of genetic variation for heat tolerance-related traits in eight crisphead lettuce cultivars (Jenni and Yan, 2009). Only a small proportion of this variation was explained by $\mathrm{G}$ with values ranging from $3 \%$ for bolted plants to $25 \%$ in number of tipburned leaves per plant (Table 2). Genetic variation for heat tolerance has been reported in rice (Ali et al., 2019), tomato (Driedonks et al., 2018), maize (Chen et al., 2012), and leaf lettuce (Lafta et al., 2017). Heat-tolerant romaine and butterhead lettuces have yet to be identified in field conditions, although there is indication of genetic variation for heat tolerance in romaine lettuce grown hydroponically in a greenhouse (Holmes et al., 2019).
A minor contribution to the variation for yield and related traits by $\mathrm{G}$ may be in part due to the narrow genetic variability in crisphead lettuce. The predominant ancestors of modern crisphead lettuce cultivars are Vanguard, Salinas, and Calmar (Mikel, 2007, 2013). 'Calmar' is a Great Lakes-type cultivar developed in the 1960s (Welch et al., 1965). 'Vanguard' has both Lactuca saligna and Lactuca serriola in its pedigree (Thompson and Ryder, 1961). 'Vanguard 75' was developed by the addition of resistance to lettuce mosaic virus to 'Vanguard' (Ryder, 1979b). 'Salinas' (Ryder, 1979a) was selected from a cross between a Vanguard-like breeding line and 'Calmar'. Among modern crisphead lettuce cultivars, the probabilities of 'Vanguard', 'Salinas', and 'Calmar' in their pedigrees are $24 \%, 12 \%$, and $11 \%$, respectively (Mikel, 2013). Hence, it can be assumed that most cultivars tested here may share common ancestors, explaining the small variation for $\mathrm{G}$.

Compared with the cool environment in Salinas (S612), 10 of the 25 cultivars had higher HW when planted at warmer Five Points in May 2012 (W512): Atlas NonBolting, Baomach, Reine des Glaces, Empire, Green Prince, Hanson Improved, Harvest Pride, Imperial 749, Oasis, and Primetime (Table 3). The warmer conditions could have promoted the growth of these cultivars leading to higher HW. In addition, five cultivars had similar HW when planted in these two environments: Calmar, Diamond, Green Lake Butterhead, Invader, and Summertime. Among these cultivars, Atlas Non-Bolting and Primetime had higher HW in the Mar. 2013 planting at Holtville (D313) than the Salinas planting (S612), whereas Calmar and Hanson Improved showed no significant difference at the two environments. All cultivars suffered significant reductions in HW when planted at Holtville in May 2012 (D512) and at Five Points in Mar. 2013 (W313), as compared with the Salinas planting. 'Primetime' had the highest HW across environments with $734 \mathrm{~g}$ per head of lettuce. This was greater than the HW for the controls 'Salinas' (633 g) and 'Vanguard 75' (585 g) (Table 3). In three (D313, W512, and S612) of the five environments, 'Primetime' had HW of more than $900 \mathrm{~g}$, higher than the HW of recently released crisphead lettuce breeding lines adapted to the California central coast which ranged from 567 to $848 \mathrm{~g}$ per head in field trials in Salinas (Hayes et al., 2018). Crossing cultivars with the highest yield in warmer conditions with cultivars that have a high yield under normal conditions is recommended as a means to combine alleles for higher yield in both environments. 'Primetime' had the most acceptable head diameter, limited bolting, and fewer leaves with tipburn per plant compared with the other tested cultivars.

One caveat with the use of 'Primetime' as breeding material is its relatively long CL. Breeders could make crosses with 'Green Lake Butterhead' for short CL, as it had the shortest CL across all environments (Table 3 ). The core in conjunction with the total HW (HW/CL ratio) is an indicator of how much of the lettuce head is useful to the market. The highest ratio is the most desirable for the lettuce industry. 'Oasis', 'Baomach', and 'Invader' had mean ratios of 10.7, 10.5, and $10.3 \mathrm{~g} / \mathrm{mm}$ (Table 4). These cultivars had greater values compared with 'Salinas' (7.1), 'Vanguard 75' (6.0), and 'Primetime' (7.3).

Although the traits mentioned previously are key to plant breeders for lettuce improvement, the crisphead breeding industry requires other characteristics to be considered. Head diameter in lettuce is an indicator of yield and certain size requirements must be met for the whole head market. 'Primetime', 'Hallmark WS', 'Diamond', and 'Salinas' had the largest diameter (Table 4). This supports the use of 'Primetime' as a source for breeding of heat tolerance.

Market maturity is a trait that indicates proper maturity at harvest. Harvesting occurred $65 \mathrm{~d}$ after planting on average, which is the standard number of days to harvest in the production locations between spring and summer in planting slots in southern California and the Salinas Valley. Despite the warmer conditions, 'Sniper' and 'Green Lake Butterhead' had mean market maturity ratings over 3 across the environments tested (Table 5). 'Glacier' and 'Oasis' had mean ratings of 2.9; 'Salinas', 'Summertime', and 'Tiber' had mean ratings of 2.8. The other cultivars did not reach the desirable maturity under the warmer conditions. No cultivar formed heads properly in the hot environment of May 2012 planting at Holtville (D512). Crisphead lettuce cultivars specifically bred for southern and inland California planting slots did not form heads when planted in the central coast of California, indicating lack of adaptability (Sandoya et al., 2017).

Acceptable heat-tolerant lettuce cultivars should not bolt under warmer conditions.

Table 2. Analyses of variance of yield, maturity, head width, core length, bolting, tipburn, and ratio of head weight to core length of 25 crisphead lettuce cultivars grown in five environments.

\begin{tabular}{|c|c|c|c|c|c|c|c|c|c|c|c|c|c|c|c|}
\hline \multirow[b]{2}{*}{ Source } & \multirow[b]{2}{*}{$\mathrm{df}^{\mathrm{z}}$} & \multicolumn{2}{|c|}{ Head wt (HW) } & \multicolumn{2}{|c|}{ Core length (CL) } & \multicolumn{2}{|c|}{$\mathrm{HW}: \mathrm{CL}$} & \multicolumn{2}{|c|}{ Head diam } & \multicolumn{2}{|c|}{ Market maturity } & \multicolumn{2}{|c|}{ Bolting } & \multicolumn{2}{|c|}{ Tipburn } \\
\hline & & $P$ & $\mathrm{SS}^{\mathrm{y}}$ & $P$ & $\mathrm{SS}$ & $P$ & SS & $P$ & $\mathrm{SS}$ & $P$ & SS & $P$ & $\mathrm{SS}$ & $P$ & SS \\
\hline$\overline{\mathrm{G}}$ & 24 & $<0.0001$ & 11.0 & $<0.0001$ & 12.7 & $<0.0001$ & 8.9 & $<0.0001$ & 17.6 & $<0.0001$ & 17.7 & $<0.0001$ & 3.3 & $<0.0001$ & 25.1 \\
\hline $\mathrm{E}$ & 4 & $<0.0001$ & 80.4 & $<0.0001$ & 71.9 & $<0.0001$ & 82.7 & $<0.0001$ & 66.5 & $<0.0001$ & 69.4 & $<0.0001$ & 88.6 & $<0.0001$ & 42.4 \\
\hline $\mathrm{G} \times \mathrm{E}$ & 96 & $<0.0001$ & 8.6 & $<0.0001$ & 15.4 & $<0.0001$ & 8.4 & $<0.0003$ & 15.8 & $<0.0001$ & 12.8 & $<0.0001$ & 8.0 & $<0.0001$ & 32.5 \\
\hline $\operatorname{Rep}(\mathrm{E})$ & 15 & 0.0169 & & $<0.0001$ & & 0.0002 & & 0.0001 & & 0.0008 & & 0.0314 & & 0.0368 & \\
\hline
\end{tabular}

$\frac{\text { Error } \quad 360}{{ }^{\mathrm{z}} \text { Degrees of freedom. }}$

${ }^{\mathrm{y}}$ Sums of squares, percentage of the total sum of squares of genotype $(\mathrm{G})$, environment $(\mathrm{E})$, and genotype $\times$ environment interaction $(\mathrm{G} \times \mathrm{E})$. 
Table 3. Head weight and core length of 25 crisphead lettuce cultivars planted in five different environments: DREC Holtville Mar. 2013 (D313) and May 2012 (D512), WSREC Five Points Mar. 2013 (W313) and May 2012 (W512), and Salinas June 2012 (S612).

\begin{tabular}{|c|c|c|c|c|c|c|c|c|c|c|c|c|}
\hline \multirow[b]{2}{*}{ Genotype } & \multicolumn{6}{|c|}{ Head wt $(\mathrm{g})$} & \multicolumn{6}{|c|}{ Core length $(\mathrm{cm})$} \\
\hline & $\overline{\mathrm{D} 313}$ & D512 & W313 & W512 & S612 & Mean $(G)$ & $\overline{\mathrm{D} 313}$ & D512 & W313 & W512 & S612 & Mean $(G)$ \\
\hline Anza & 557 & 199 & 439 & 662 & 759 & 523 & 18.0 & 48.3 & 4.5 & 37.2 & 3.1 & 22.2 \\
\hline Atlas Non-bolting & 707 & 262 & 320 & 762 & 634 & 537 & 26.1 & 62.0 & 3.7 & 45.6 & 3.8 & 28.2 \\
\hline Badger & 640 & 270 & 404 & 626 & 875 & 563 & 29.5 & 49.3 & 4.5 & 37.0 & 4.6 & 25.0 \\
\hline Baomach & 668 & 218 & 351 & 998 & 760 & 599 & 5.4 & 31.8 & 2.8 & 17.8 & 3.9 & 12.3 \\
\hline Barcelona & 514 & 91 & 349 & 724 & 962 & 528 & 8.3 & 26.5 & 4.6 & 29.8 & 6.5 & 15.1 \\
\hline Barrier Reef & 722 & 220 & 435 & 833 & 1054 & 653 & 8.9 & 27.1 & 5.3 & 27.2 & 7.7 & 15.2 \\
\hline Calmar & 750 & 153 & 553 & 807 & 783 & 609 & 7.3 & 34.4 & 4.0 & 19.5 & 4.1 & 13.9 \\
\hline Diamond & 607 & 214 & 512 & 889 & 876 & 620 & 7.5 & 40.1 & 4.6 & 21.2 & 5.2 & 15.7 \\
\hline Empire & 559 & 106 & 278 & 943 & 725 & 522 & 4.6 & 26.0 & 2.8 & 15.1 & 3.9 & 10.5 \\
\hline Glacier & 711 & 141 & 477 & 913 & 1141 & 677 & 9.7 & 32.3 & 5.2 & 25.3 & 7.6 & 16.0 \\
\hline Green Lake Butterhead & 335 & 83 & 253 & 643 & 678 & 399 & 3.5 & 13.8 & 3.0 & 9.5 & 3.9 & 6.7 \\
\hline Green Prince & 634 & 270 & 465 & 908 & 824 & 620 & 6.3 & 35.6 & 3.8 & 19.8 & 4.0 & 13.9 \\
\hline Hallmark WS & 673 & 267 & 489 & 982 & 1046 & 692 & 10.2 & 52.8 & 5.6 & 44.8 & 6.4 & 23.9 \\
\hline Hanson Improved & 367 & 164 & 315 & 593 & 366 & 361 & 19.9 & 49.2 & 7.0 & 50.7 & 5.3 & 26.4 \\
\hline Harvest Pride & 567 & 177 & 511 & 819 & 755 & 566 & 8.1 & 30.3 & 4.8 & 28.0 & 5.0 & 15.3 \\
\hline Imperial 749 & 624 & 192 & 383 & 958 & 899 & 611 & 11.9 & 45.5 & 4.5 & 42.3 & 5.2 & 21.9 \\
\hline Invader & 647 & 276 & 352 & 856 & 825 & 591 & 5.2 & 47.2 & 3.7 & 9.4 & 4.2 & 13.9 \\
\hline Oasis & 503 & 121 & 291 & 767 & 717 & 480 & 3.4 & 24.0 & 2.6 & 17.3 & 3.4 & 10.1 \\
\hline Primetime & 978 & 280 & 498 & 990 & 925 & 734 & 13.1 & 30.0 & 5.6 & 28.8 & 5.9 & 16.7 \\
\hline Reine des Glaces & 359 & 255 & 215 & 648 & 572 & 410 & 8.2 & 60.7 & 3.6 & 44.2 & 5.2 & 24.4 \\
\hline Salinas & 700 & 188 & 445 & 857 & 975 & 633 & 10.2 & 27.8 & 4.9 & 32.0 & 6.1 & 16.2 \\
\hline Sniper & 681 & 178 & 474 & 884 & 934 & 630 & 9.3 & 28.9 & 5.2 & 35.1 & 6.4 & 17.0 \\
\hline Summertime & 559 & 158 & 349 & 694 & 683 & 489 & 4.9 & 26.3 & 3.5 & 16.8 & 4.4 & 11.2 \\
\hline Tiber & 843 & 196 & 456 & 843 & 894 & 646 & 7.5 & 29.4 & 4.3 & 22.3 & 4.9 & 13.7 \\
\hline Vanguard 75 & 667 & 155 & 355 & 772 & 976 & 585 & 25.4 & 28.0 & 4.1 & 27.9 & 6.4 & 18.4 \\
\hline Mean (E) & 623 & 193 & 399 & 815 & 825 & 571.1 & 10.9 & 36.3 & 4.3 & 28.2 & 5.1 & 17.0 \\
\hline $\mathrm{LSD}_{0.05}$ for $\mathrm{E}$ & 50 & & & & & & 5.3 & & & & & \\
\hline $\mathrm{LSD}_{0.05}$ for $\mathrm{G}$ & 74 & & & & & & 4.8 & & & & & \\
\hline $\mathrm{LSD}_{0.05}$ for $\mathrm{E} \times \mathrm{G}$ & 165 & & & & & & 10.8 & & & & & \\
\hline
\end{tabular}

$\mathrm{G}=$ genotype; $\mathrm{E}=$ environment; LSD = least significant difference.

Table 4. Ratio of head weight/core length and head diameter of 25 lettuce cultivars planted in five different environments: DREC Holtville Mar. 2013 (D313) and May 2012 (D512), WSREC Five Points Mar. 2013 (W313) and May 2012 (W512), and Salinas June 2012 (S612).

\begin{tabular}{|c|c|c|c|c|c|c|c|c|c|c|c|c|}
\hline \multirow[b]{2}{*}{ Genotype } & \multicolumn{6}{|c|}{ Head wt/core length $(\mathrm{g} / \mathrm{mm})$} & \multicolumn{6}{|c|}{ Head diam $(\mathrm{cm})$} \\
\hline & D313 & D512 & W313 & W512 & S612 & Mean $(G)$ & D313 & D512 & W313 & W512 & S612 & Mean $(G)$ \\
\hline Anza & 3.5 & 0.5 & 9.9 & 1.8 & 25.0 & 8.1 & 12.8 & 8.8 & 13.2 & 13.6 & 13.6 & 12.4 \\
\hline Atlas Non-Bolting & 2.8 & 0.4 & 8.6 & 1.7 & 16.5 & 6.0 & 12.9 & 11.2 & 12.3 & 12.8 & 10.9 & 12.0 \\
\hline Badger & 2.2 & 0.6 & 9.5 & 1.8 & 19.4 & 6.7 & 14.3 & 10.8 & 12.9 & 13.8 & 14.3 & 13.2 \\
\hline Baomach & 12.5 & 0.9 & 13.0 & 5.7 & 20.5 & 10.5 & 14.0 & 10.4 & 11.8 & 17.7 & 13.9 & 13.6 \\
\hline Barcelona & 6.3 & 0.4 & 7.8 & 2.5 & 15.1 & 6.4 & 13.6 & 7.8 & 12.4 & 16.1 & 15.1 & 13.0 \\
\hline Barrier Reef & 8.2 & 0.8 & 8.1 & 3.7 & 13.8 & 6.9 & 14.7 & 10.4 & 12.4 & 16.7 & 15.3 & 13.9 \\
\hline Calmar & 10.3 & 0.5 & 14.0 & 4.3 & 19.7 & 9.8 & 14.9 & 11.9 & 13.0 & 15.4 & 14.2 & 13.9 \\
\hline Diamond & 8.3 & 0.6 & 11.4 & 4.5 & 16.9 & 8.3 & 14.3 & 11.6 & 12.7 & 17.6 & 15.2 & 14.3 \\
\hline Empire & 12.2 & 0.4 & 10.2 & 8.1 & 18.6 & 9.9 & 13.9 & 8.6 & 11.2 & 15.9 & 13.4 & 12.6 \\
\hline Glacier & 7.4 & 0.5 & 9.1 & 3.7 & 15.0 & 7.1 & 14.3 & 10.1 & 13.4 & 16.6 & 15.3 & 13.9 \\
\hline Green Lake Butterhead & 9.2 & 0.6 & 8.5 & 6.9 & 17.4 & 8.5 & 10.6 & 8.7 & 9.8 & 13.5 & 12.8 & 11.1 \\
\hline Green Prince & 10.5 & 0.9 & 12.3 & 4.7 & 20.5 & 9.8 & 13.6 & 13.1 & 11.6 & 15.7 & 14.7 & 13.7 \\
\hline Hallmark WS & 6.5 & 0.5 & 9.0 & 2.4 & 16.5 & 7.0 & 14.5 & 12.3 & 13.4 & 15.5 & 15.7 & 14.3 \\
\hline Hanson Improved & 1.9 & 0.3 & 4.5 & 1.2 & 7.3 & 3.0 & 12.1 & 8.0 & 13.7 & 11.8 & 12.2 & 11.5 \\
\hline Harvest Pride & 7.1 & 0.7 & 10.5 & 4.1 & 15.2 & 7.5 & 13.8 & 10.4 & 14.4 & 15.3 & 14.7 & 13.7 \\
\hline Imperial 749 & 5.4 & 0.6 & 8.6 & 2.5 & 17.5 & 6.9 & 14.0 & 11.6 & 12.8 & 15.5 & 14.6 & 13.7 \\
\hline Invader & 12.6 & 0.7 & 9.5 & 9.3 & 19.6 & 10.3 & 13.9 & 10.0 & 13.0 & 14.6 & 14.3 & 13.2 \\
\hline Oasis & 15.1 & 0.5 & 11.6 & 5.6 & 20.6 & 10.7 & 12.5 & 9.5 & 11.0 & 14.4 & 13.3 & 12.1 \\
\hline Primetime & 7.5 & 0.9 & 8.9 & 3.5 & 15.5 & 7.3 & 15.2 & 10.4 & 13.5 & 17.6 & 14.8 & 14.3 \\
\hline Reine des Glaces & 4.9 & 0.4 & 6.0 & 1.6 & 11.4 & 4.8 & 13.1 & 10.0 & 10.8 & 13.2 & 12.9 & 12.0 \\
\hline Salinas & 7.1 & 0.7 & 9.1 & 2.7 & 16.2 & 7.1 & 14.4 & 12.4 & 12.6 & 15.3 & 15.8 & 14.1 \\
\hline Sniper & 7.3 & 0.8 & 9.1 & 2.6 & 14.6 & 6.9 & 13.5 & 8.7 & 12.5 & 15.7 & 15.3 & 13.1 \\
\hline Summertime & 11.4 & 0.7 & 9.9 & 4.3 & 15.5 & 8.4 & 13.4 & 9.3 & 11.8 & 14.3 & 14.2 & 12.6 \\
\hline Tiber & 11.3 & 0.8 & 10.6 & 4.2 & 18.0 & 9.0 & 14.3 & 9.9 & 12.6 & 15.8 & 15.5 & 13.6 \\
\hline Vanguard 75 & 2.6 & 0.5 & 8.8 & 2.8 & 15.4 & 6.0 & 13.1 & 10.1 & 12.3 & 16.1 & 15.5 & 13.4 \\
\hline Mean (E) & 7.8 & 0.6 & 9.5 & 3.8 & 16.9 & 7.7 & 13.7 & 10.2 & 12.4 & 15.2 & 14.3 & 13.2 \\
\hline $\mathrm{LSD}_{0.05}$ for $\mathrm{E}$ & 0.9 & & & & & & 1.2 & & & & & \\
\hline $\mathrm{LSD}_{0.05}$ for $\mathrm{G}$ & 1.1 & & & & & & 0.9 & & & & & \\
\hline $\mathrm{LSD}_{0.05}$ for $\mathrm{E} \times \mathrm{G}$ & 2.4 & & & & & & 2.0 & & & & & \\
\hline
\end{tabular}

$\mathrm{G}=$ genotype $\mathrm{E}=$ environment LSD = least significant difference.

'Invader' (18\%) and 'Green Lake Butterhead' $(20 \%)$ had the fewest number of heads bolted and were significantly different from both controls (Table 5). Bolting is a complex trait with an important genetic component. For example, PI 251246 flowers as early as $30 \mathrm{~d}$ from seeding (Ryder and Milligan, 2005), whereas Lactuca virosa species, a wild relative of cultivated lettuce, bolts and flowers on a biennial basis (Ryder, 1999). The trait is also influenced by heat waves during the growing season, as 
Table 5. Market maturity and percent bolted heads of 25 crisphead lettuce cultivars planted in five different environments: DREC Holtville Mar. 2013 (D313) and May 2012 (D512), WSREC Five Points Mar. 2013 (W313) and May 2012 (W512), and Salinas June 2012 (S612).

\begin{tabular}{|c|c|c|c|c|c|c|c|c|c|c|c|c|}
\hline \multirow[b]{2}{*}{ Genotype } & \multicolumn{6}{|c|}{ Market maturity } & \multicolumn{6}{|c|}{ Percent bolted heads } \\
\hline & $\overline{\text { D313 }}$ & D512 & W313 & W512 & S612 & Mean $(G)$ & D313 & D512 & W313 & W512 & S612 & Mean $(\mathrm{G})$ \\
\hline Anza & 3.2 & 1.0 & 3.1 & 1.7 & 3.3 & 2.4 & 25 & 100 & 0 & 75 & 0 & 40 \\
\hline Atlas Non-Bolting & 2.1 & 1.0 & 2.0 & 1.3 & 1.3 & 1.5 & 33 & 100 & 0 & 100 & 0 & 47 \\
\hline Badger & 2.6 & 1.0 & 3.3 & 1.5 & 2.4 & 2.2 & 33 & 100 & 0 & 83 & 0 & 43 \\
\hline Baomach & 3.5 & 1.0 & 3.1 & 2.9 & 2.9 & 2.7 & 0 & 100 & 0 & 33 & 0 & 27 \\
\hline Barcelona & 3.3 & 1.0 & 2.9 & 2.9 & 3.7 & 2.7 & 0 & 100 & 0 & 50 & 8 & 32 \\
\hline Barrier Reef & 3.4 & 1.0 & 3.2 & 2.2 & 3.8 & 2.7 & 0 & 100 & 0 & 58 & 0 & 32 \\
\hline Calmar & 3.4 & 1.0 & 3.5 & 3.0 & 2.9 & 2.7 & 0 & 100 & 0 & 42 & 0 & 28 \\
\hline Diamond & 3.1 & 1.0 & 3.4 & 2.5 & 3.4 & 2.7 & 0 & 100 & 0 & 33 & 0 & 27 \\
\hline Empire & 2.7 & 1.0 & 2.5 & 2.3 & 2.7 & 2.2 & 0 & 100 & 0 & 25 & 0 & 25 \\
\hline Glacier & 3.9 & 1.0 & 3.3 & 2.3 & 4.0 & 2.9 & 3 & 100 & 0 & 58 & 0 & 32 \\
\hline Green Lake Butterhead & 3.7 & 1.0 & 3.5 & 3.6 & 3.7 & 3.1 & 0 & 100 & 0 & 0 & 0 & 20 \\
\hline Green Prince & 3.5 & 1.0 & 3.4 & 2.3 & 3.1 & 2.7 & 0 & 100 & 0 & 58 & 0 & 32 \\
\hline Hallmark WS & 3.5 & 1.0 & 3.3 & 1.6 & 3.6 & 2.6 & 3 & 100 & 0 & 100 & 8 & 42 \\
\hline Hanson Improved & 2.0 & 1.0 & 2.3 & 1.0 & 1.5 & 1.6 & 28 & 100 & 0 & 100 & 0 & 46 \\
\hline Harvest Pride & 3.3 & 1.0 & 3.5 & 2.0 & 3.3 & 2.6 & 0 & 100 & 0 & 67 & 0 & 33 \\
\hline Imperial 749 & 2.9 & 1.0 & 2.4 & 1.8 & 2.5 & 2.1 & 17 & 100 & 0 & 83 & 0 & 40 \\
\hline Invader & 3.2 & 1.0 & 2.8 & 3.3 & 3.4 & 2.7 & 0 & 89 & 0 & 0 & 0 & 18 \\
\hline Oasis & 3.7 & 1.0 & 3.3 & 3.2 & 3.1 & 2.9 & 0 & 100 & 0 & 25 & 0 & 25 \\
\hline Primetime & 3.3 & 1.0 & 2.4 & 2.5 & 2.8 & 2.4 & 6 & 100 & 0 & 50 & 0 & 31 \\
\hline Reine des Glaces & 2.6 & 1.0 & 2.3 & 1.4 & 1.3 & 1.7 & 3 & 100 & 0 & 100 & 0 & 41 \\
\hline Salinas & 3.5 & 1.0 & 3.2 & 2.7 & 3.5 & 2.8 & 3 & 100 & 0 & 50 & 0 & 31 \\
\hline Sniper & 3.8 & 1.0 & 3.5 & 3.0 & 3.5 & 3.0 & 0 & 100 & 0 & 83 & 0 & 37 \\
\hline Summertime & 3.6 & 1.0 & 3.4 & 2.6 & 3.4 & 2.8 & 0 & 100 & 0 & 33 & 0 & 27 \\
\hline Tiber & 3.7 & 1.0 & 3.5 & 2.3 & 3.4 & 2.8 & 0 & 100 & 0 & 33 & 0 & 27 \\
\hline Vanguard 75 & 2.2 & 1.0 & 2.6 & 2.0 & 3.6 & 2.3 & 31 & 100 & 0 & 58 & 0 & 38 \\
\hline Mean (E) & 3.2 & 1.0 & 3.0 & 2.3 & 3.0 & 2.5 & 7 & 100 & 0 & 56 & 1 & 32.8 \\
\hline $\mathrm{LSD}_{0.05}$ for $\mathrm{E}$ & 0.2 & & & & & & 6 & & & & & \\
\hline $\mathrm{LSD}_{0.05}$ for $\mathrm{G}$ & 0.3 & & & & & & 10 & & & & & \\
\hline $\mathrm{LSD}_{0.05}$ for $\mathrm{E} \times \mathrm{G}$ & 0.6 & & & & & & 22 & & & & & \\
\hline
\end{tabular}

$\mathrm{G}=$ genotype; $\mathrm{E}=$ environment; $\mathrm{LSD}=$ least significant difference.

demonstrated in this research; the percentage of bolted plants was $\approx 33 \%$ across the environments tested, with a maximum of $47 \%$ bolting.

It was expected that heat-tolerant cultivars would have the fewest number of leaves damaged by tipburn. The number of leaves with tipburn per plant ranged from 2.1 ('Tiber') to 11.3 ('Anza') (Table 6). 'Tiber' and 'Anza' differed significantly from 'Vanguard 75', which exhibited 8.6 leaves with tipburn per plant. The addition of 'Tiber' to the breeding pool is recommended, as it was selected for tipburn resistance (Ryder and Waycott, 1998). As expected, the heattolerant cultivars Tiber and Primetime were among the cultivars with the least number of tipburned leaves. Our results are consistent with the findings of Jenni and Hayes (2010), who identified 'Tiber' (34.3\% of plants with tipburn on average), 'Diamond' (34.3), 'Salinas' (37.6), and 'Sniper' (39.1\%) with stable tipburn resistance as compared with 'Vanguard 75' (49.3\%) and 'Calmar' $(51.5 \%)$ across four field trials in 2005 and 2006 in Salinas and Yuma, AZ, which is close to our experiment location Holtville, CA. Jenni and Yan (2009) also found 'Summertime' to be resistant to tipburn but susceptible to rib discoloration and bolting in Quebec, Canada.

Environmental effects accounted for the largest variation in all crisphead characteristics. The variations due to E were $80 \%, 72 \%$, $83 \%, 67 \%, 69 \%, 89 \%$, and $42 \%$ for HW, CL, $\mathrm{HW} / \mathrm{CL}$ ratio, head diameter, market maturity, percentage of bolted plants, and total

Table 6. Tipburn incidence (number of leaves per plant) on 25 crisphead lettuce cultivars planted in five different environments: DREC Holtville Mar. 2013 (D313) and May 2012 (D512), WSREC Five Points Mar. 2013 (W313) and May 2012 (W512), and Salinas June 2012 (S612).

\begin{tabular}{|c|c|c|c|c|c|c|}
\hline \multirow[b]{2}{*}{ Genotype } & \multicolumn{6}{|c|}{ Tipburn (leaves/plant) } \\
\hline & $\overline{\mathrm{D} 313}$ & D512 & W313 & W512 & S612 & Mean $(\mathrm{G})$ \\
\hline Anza & 15.5 & 9.8 & 9.6 & 21.4 & 0.0 & 11.3 \\
\hline Atlas Non-Bolting & 14.8 & 11.7 & 4.7 & 14.6 & 0.0 & 9.2 \\
\hline Badger & 20.9 & 13.3 & 8.1 & 11.8 & 0.4 & 10.9 \\
\hline Baomach & 8.4 & 6.2 & 3.8 & 10.2 & 0.5 & 5.8 \\
\hline Barcelona & 1.2 & 5.6 & 3.2 & 15.0 & 0.0 & 5.0 \\
\hline Barrier Reef & 2.9 & 5.7 & 3.4 & 5.3 & 0.0 & 3.5 \\
\hline Calmar & 4.4 & 11.3 & 3.8 & 6.5 & 0.0 & 5.2 \\
\hline Diamond & 0.1 & 7.4 & 1.2 & 10.3 & 0.0 & 3.8 \\
\hline Empire & 13.4 & 6.9 & 6.9 & 13.0 & 0.0 & 8.1 \\
\hline Glacier & 4.3 & 6.1 & 3.6 & 17.6 & 0.0 & 6.3 \\
\hline Green Lake Butterhead & 5.4 & 3.3 & 6.7 & 9.0 & 0.0 & 4.9 \\
\hline Green Prince & 4.3 & 4.6 & 4.2 & 5.4 & 0.0 & 3.7 \\
\hline Hallmark WS & 0.5 & 5.2 & 0.5 & 5.6 & 0.5 & 2.5 \\
\hline Hanson Improved & 5.1 & 10.7 & 4.8 & 18.5 & 0.0 & 7.8 \\
\hline Harvest Pride & 1.9 & 7.1 & 1.9 & 5.0 & 0.0 & 3.2 \\
\hline Imperial 749 & 12.8 & 6.8 & 6.3 & 8.3 & 0.8 & 7.0 \\
\hline Invader & 0.4 & 11.7 & 2.5 & 1.5 & 0.0 & 3.2 \\
\hline Oasis & 9.1 & 4.8 & 3.2 & 7.2 & 0.0 & 4.9 \\
\hline Primetime & 0.9 & 6.7 & 1.8 & 3.7 & 0.0 & 2.6 \\
\hline Reine des Glaces & 3.8 & 14.0 & 4.3 & 14.4 & 0.0 & 7.3 \\
\hline Salinas & 1.4 & 8.4 & 1.2 & 5.3 & 0.0 & 3.3 \\
\hline Sniper & 1.7 & 4.8 & 2.6 & 10.5 & 0.0 & 3.9 \\
\hline Summertime & 1.8 & 7.1 & 0.6 & 8.0 & 0.0 & 3.5 \\
\hline Tiber & 0.4 & 4.5 & 0.9 & 4.8 & 0.0 & 2.1 \\
\hline Vanguard 75 & 18.4 & 7.5 & 4.2 & 12.9 & 0.0 & 8.6 \\
\hline Mean (E) & 6.2 & 7.6 & 3.7 & 9.8 & 0.1 & 5.5 \\
\hline $\mathrm{LSD}_{0.05}$ for $\mathrm{E}$ & 1.5 & & & & & \\
\hline $\mathrm{LSD}_{0.05}$ for $\mathrm{G}$ & 2.3 & & & & & \\
\hline $\mathrm{LSD}_{0.05}$ for $\mathrm{E} \times \mathrm{G}$ & 5.1 & & & & & \\
\hline
\end{tabular}

$\mathrm{G}=$ genotype; $\mathrm{E}=$ environment; $\mathrm{LSD}$ = least significant difference.

leaves with tipburn, respectively (Table 2). Two of the five environments were in the Imperial Valley (DREC, Mar. 2013; DREC, May 2012), two environments were in the
San Joaquin Valley (WSREC, Mar. 2013, WSREC, May 2012), and a fifth environment in the Salinas Valley (Salinas June 2012). Mean daily temperature at WSREC ranged 
Table 7. Monthly averages of daily maximum, mean, and minimum temperatures $\left({ }^{\circ} \mathrm{C}\right)$, wind velocity, daylength, and precipitation during field trials in Five Points (W313 and W512 at WSREC), Holtville (D313 and D512 at DREC), and Salinas (S612), California in 2012 and 2013.

\begin{tabular}{|c|c|c|c|c|c|c|c|c|c|c|c|c|}
\hline \multirow[b]{3}{*}{ Location } & \multirow[b]{3}{*}{ Month } & \multicolumn{6}{|c|}{ Temperature $\left({ }^{\circ} \mathrm{C}\right)$} & & & \multirow{3}{*}{$\frac{\text { Day length }}{2012-13}$} & \multirow{2}{*}{\multicolumn{2}{|c|}{ Precipitation $(\mathrm{cm})$}} \\
\hline & & \multicolumn{2}{|c|}{ Maximum } & \multicolumn{2}{|c|}{ Mean } & \multicolumn{2}{|c|}{ Minimum } & \multicolumn{2}{|c|}{ Wind velocity $\left(\mathrm{km} \cdot \mathrm{h}^{-1}\right)$} & & & \\
\hline & & 2012 & 2013 & 2012 & 2013 & 2012 & 2013 & 2012 & 2013 & & 2012 & 2013 \\
\hline \multirow[t]{6}{*}{ WSREC } & March & 20 & 24 & 13 & 16 & 7 & 7 & 13 & 5 & $11 \mathrm{~h} 57 \mathrm{~m}$ & 0.08 & 0.84 \\
\hline & April & 24 & 28 & 16 & 19 & 8 & 9 & 13 & 7 & $13 \mathrm{~h} 08 \mathrm{~m}$ & 0.08 & 0.02 \\
\hline & May & 31 & 31 & 21 & 22 & 11 & 12 & 15 & 9 & $14 \mathrm{~h} 07 \mathrm{~m}$ & 0.01 & 0.05 \\
\hline & June & 33 & 36 & 23 & 26 & 13 & 15 & 16 & 9 & $14 \mathrm{~h} 37 \mathrm{~m}$ & 0.00 & 0.00 \\
\hline & July & 36 & 39 & 26 & 29 & 16 & 18 & 11 & 7 & $14 \mathrm{~h} 23 \mathrm{~m}$ & 0.00 & 0.00 \\
\hline & August & 38 & 38 & 27 & 27 & 17 & 17 & 13 & 8 & $13 \mathrm{~h} 31 \mathrm{~m}$ & 0.00 & 0.00 \\
\hline \multirow[t]{6}{*}{ DREC } & March & 26 & 29 & 18 & 20 & 9 & 10 & 11 & 7 & $11 \mathrm{~h} 58 \mathrm{~m}$ & 0.00 & 0.03 \\
\hline & April & 31 & 31 & 22 & 22 & 13 & 13 & 13 & 9 & $13 \mathrm{~h} 00 \mathrm{~m}$ & 0.01 & 0.00 \\
\hline & May & 38 & 35 & 27 & 29 & 18 & 17 & 11 & 9 & $13 \mathrm{~h} 51 \mathrm{~m}$ & 0.00 & 0.00 \\
\hline & June & 41 & 41 & 31 & 32 & 22 & 23 & 13 & 7 & $14 \mathrm{~h} 18 \mathrm{~m}$ & 0.00 & 0.00 \\
\hline & July & 41 & 41 & 33 & 34 & 26 & 28 & 11 & 7 & $14 \mathrm{~h} 05 \mathrm{~m}$ & 0.08 & 0.00 \\
\hline & August & 41 & 41 & 35 & 36 & 28 & 26 & 10 & 6 & $13 \mathrm{~h} 20 \mathrm{~m}$ & 0.00 & 0.56 \\
\hline \multirow[t]{3}{*}{ Salinas } & June & 22 & - & 17 & - & 11 & - & 15 & - & $14 \mathrm{~h} 39 \mathrm{~m}$ & 0.01 & - \\
\hline & July & 21 & - & 17 & - & 13 & - & 13 & - & $14 \mathrm{~h} 24 \mathrm{~m}$ & 0.00 & - \\
\hline & August & 22 & - & 17 & - & 13 & - & 13 & - & $13 \mathrm{~h} 32 \mathrm{~m}$ & 0.00 & - \\
\hline
\end{tabular}

Source: Weather Underground. Weather history. https://www.wunderground.com/history. Accessed 6 May 2020.

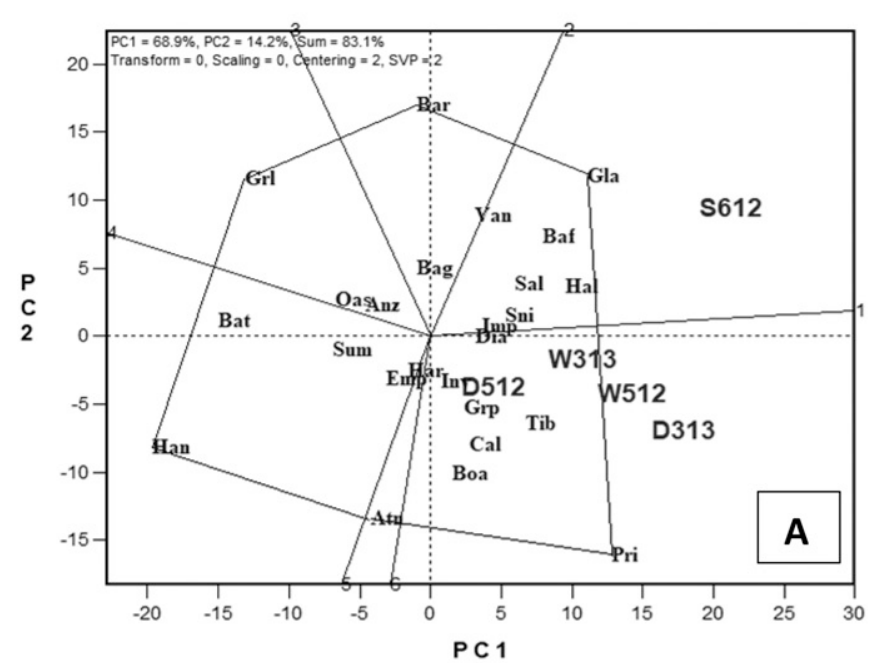

Which wins where or which is best for what

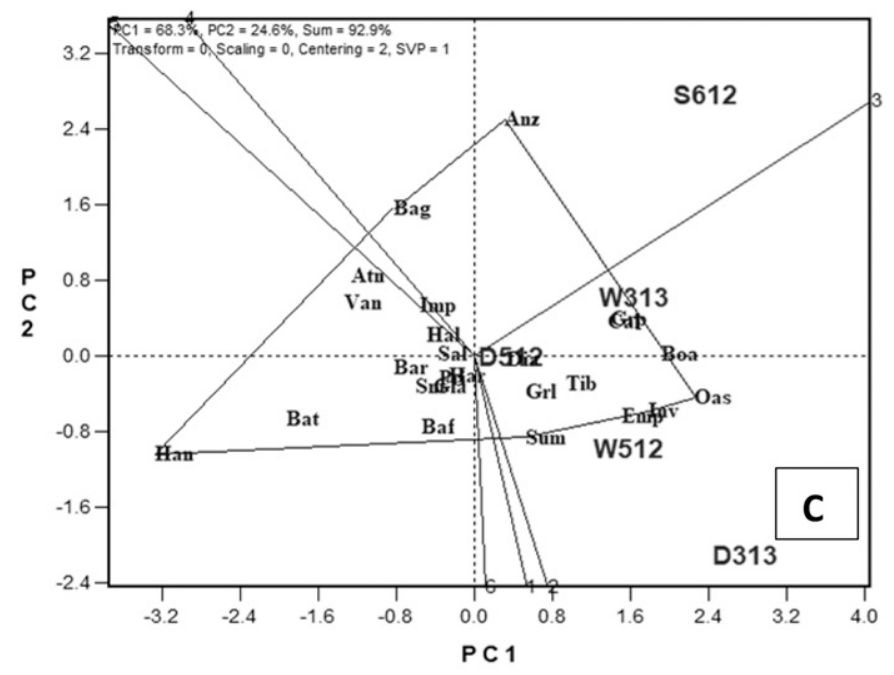

Which wins where or which is best for what

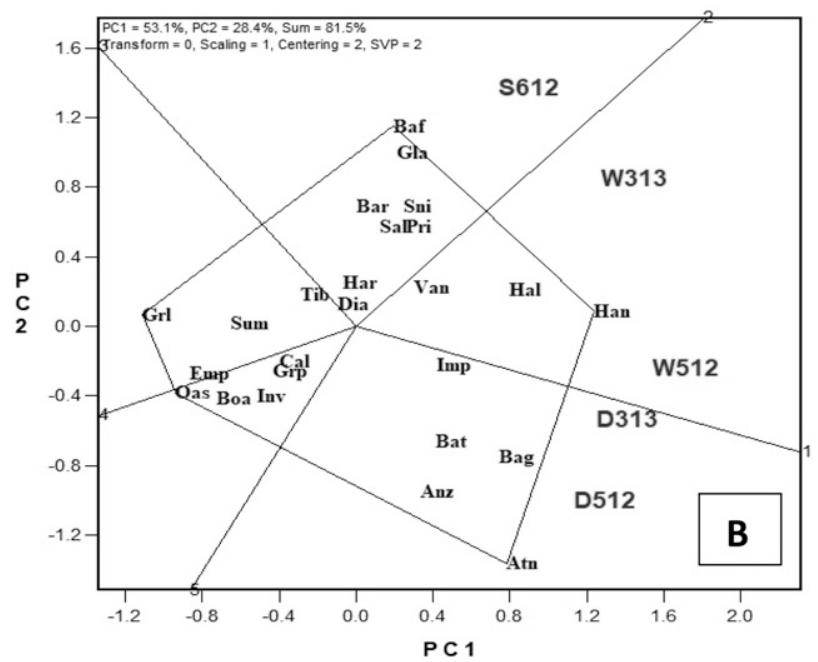

Which wins where or which is best for what

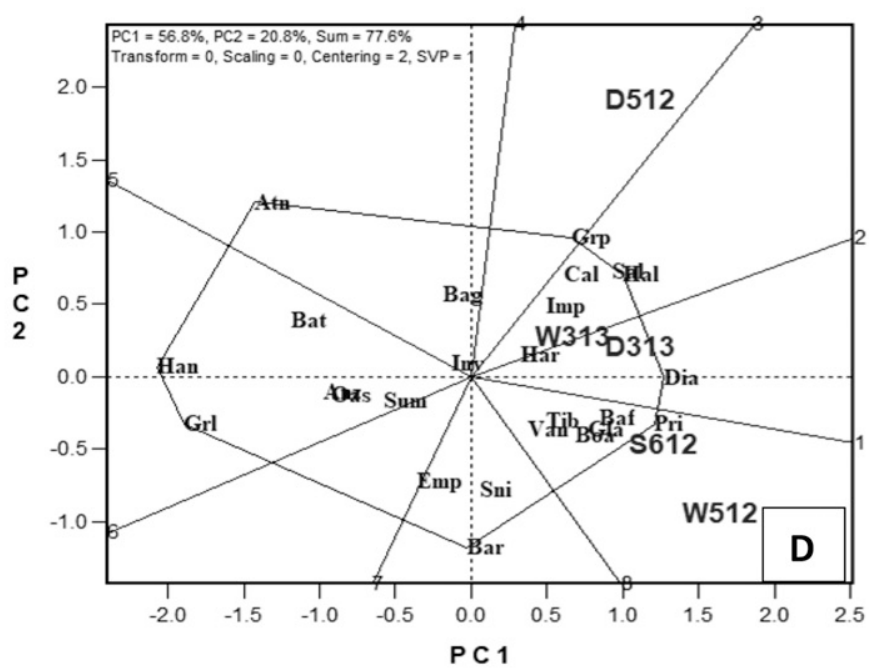

Which wins where or which is best for what

Fig. 1. Which-won-where view of the GGE biplot showing the performance of crisphead lettuce genotypes for head weight (A), core length (B), the ratio of head weight to core length $(\mathbf{C})$, head diameter $(\mathbf{D})$, market maturity $(\mathbf{E})$, bolting $(\mathbf{F})$, and tipburn $(\mathbf{G})$. Environments are represented by D313 (Holtville, CA, March 2013 planting), D512 (Holtville, CA, May 2012 planting), W313 (Five Points, CA, March 2013 planting), W512 (Five Points, CA, May 2012 planting), and S612 (Salinas, CA, June 2012 planting). 
from 13 to $27{ }^{\circ} \mathrm{C}$ from March to August in 2012 and 16 to $29{ }^{\circ} \mathrm{C}$ in 2013 with a maximum of 38 to $39^{\circ} \mathrm{C}$ in both years (Table 7). Warmer temperatures were registered at DREC during these experiments, where mean daily temperatures ranged from 18 to $35^{\circ} \mathrm{C}$ in 2012 and 20 to $36{ }^{\circ} \mathrm{C}$ in 2013 with a maximum of $41{ }^{\circ} \mathrm{C}$.

Overall, temperatures in 2013 were higher than in 2012 (Table 7). Milder temperatures were observed in Salinas with steady mean temperatures of $17^{\circ} \mathrm{C}$ from June to August (Table 7). As most of the variation in this experiment was explained by $\mathrm{E}$, it is notable that the environment at DREC May 2012 experiment was the worst location-year combination in terms of head quality for production of crisphead lettuce. Between planting in May and the end of the experiment in July 2012, maximum temperatures ranged from 38 to $41{ }^{\circ} \mathrm{C}$ at DREC, making this location unacceptable for lettuce production at that time of the year. A significantly lower HW was obtained from DREC May 2012 planting (193 g). This environment also produced lettuce with the longest $\mathrm{CL}(36.3 \mathrm{~cm})$ on average, the smallest ratio $(0.6 \mathrm{~g} / \mathrm{mm})$ of $\mathrm{HW} / \mathrm{CL}$, the smallest mean head diameter $(10.2 \mathrm{~cm})$, market maturity not reached (1.0), and $100 \%$ of the crisphead lettuce plants bolted. A greater number of leaves with tipburn per plant was registered in the WSREC May 2012 planting followed by DREC May 2012 ( 9.8 and 7.6, respectively) (Tables 3-6).

These findings indicate that planting crisphead lettuce in or around the summer, especially in DREC, is not recommended. However, planting in spring (March planting) when the weather is still not too hot for lettuce production may produce a suitable crisphead crop for lettuce growers. Currently, in southwestern locations, plantings generally occur from September to January and harvesting runs from November until April, with occasional harvests in May. Improvement of heat-tolerant cultivars may aid these production areas by extending their season until June each year.

The best environment to produce lettuce was Salinas in June 2012. This is the environment with the highest mean head weight and better traits such as shorter CL, higher HW/CL ratio, larger diameter, perfect market maturity, and little bolting or tipburn. Although the experiment was planted in June, the average maximum temperature during this period in 2012 was $21^{\circ} \mathrm{C}$, which was lower than in the other two locations. The Salinas Valley of California is a unique environment for vegetable production with mild temperatures all year round, even in the summer (Table 7). In addition, most cultivars used in this study were improved for the California coast production areas and may be adapted to longer photoperiods.

Although it is true that central California coastal production regions (e.g., Santa MariaOxnard, Salinas, and Pajaro Valleys) provide lettuce to the entire U.S. markets from April through the fall (Simko et al., 2014), sometimes lettuce shortages occur due to weatherrelated issues (i.e., untimely rain, at the beginning and end of the coastal production season) and therefore there is a window of opportunity for the inland and deserts of California and the hot, subtropical area of Florida

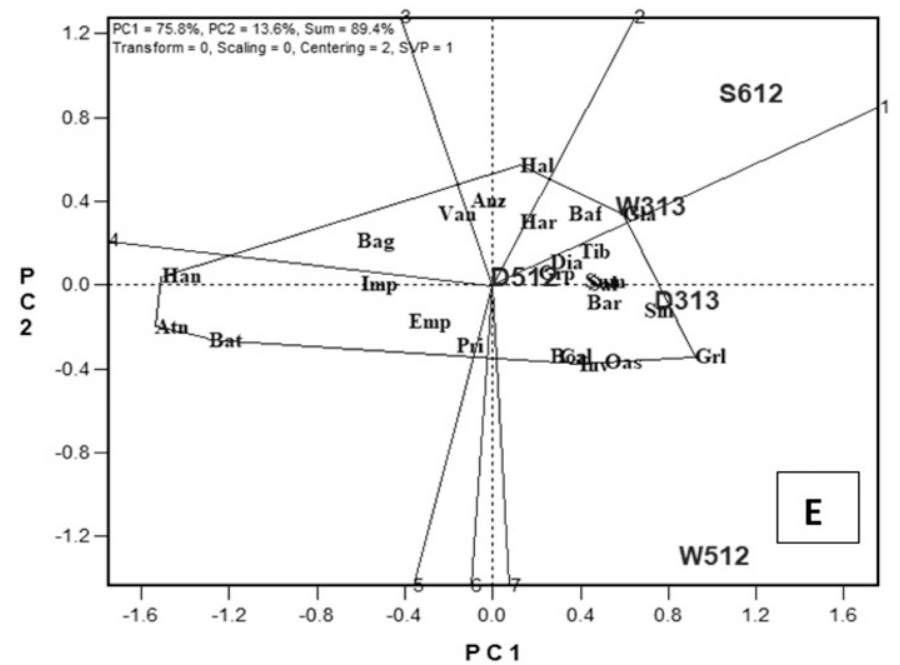

Which wins where or which is best for what

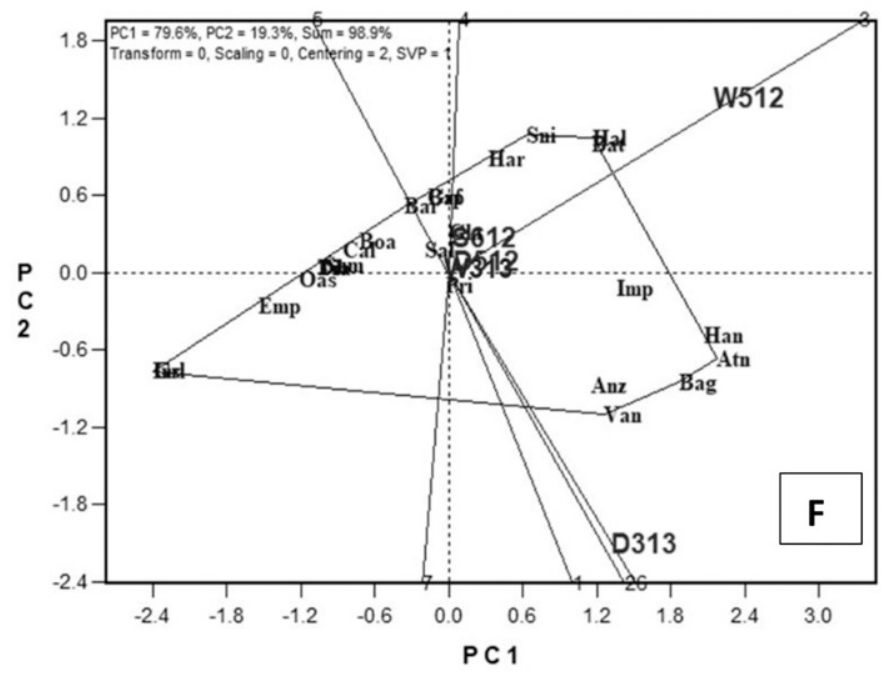

Which wins where or which is best for what

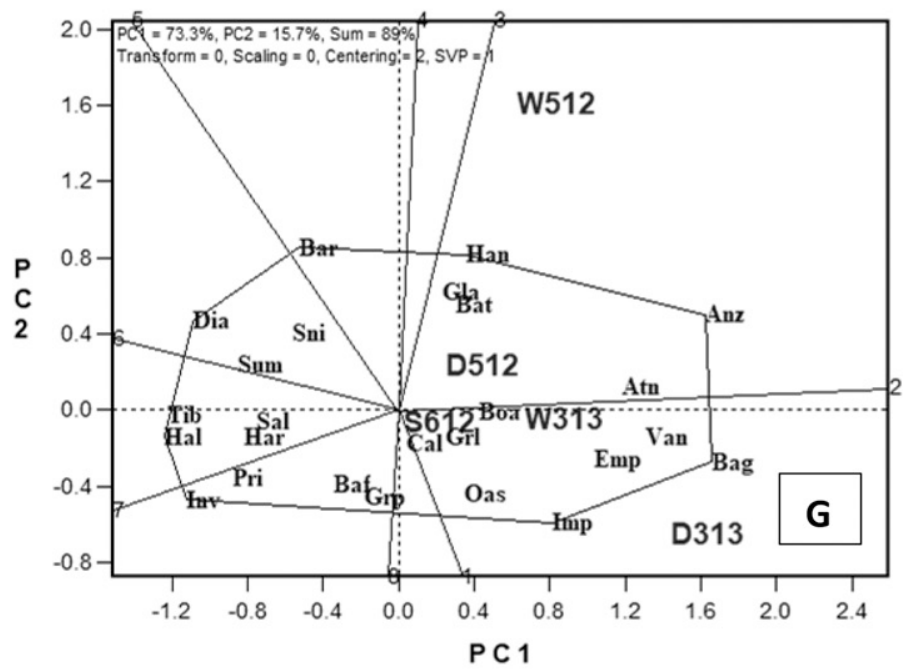

Which wins where or which is best for what

Fig. 1. (Continued) 
with heat-tolerant lettuce cultivars to provide for these shortages. Land value in the Salinas Valley is two to four times that of the land value in the San Joaquin and Imperial Valleys (Campbell, 2007); therefore, expanding the growing seasons of lettuce in hot but low land-cost areas, such as the San Joaquin Valley or Imperial Valley, may reduce land and production costs and improve the sustainability and profitability of U.S. lettuce crops.

$G \times E$ interaction for heat tolerance in lettuce. Variations due to $\mathrm{G} \times \mathrm{E}$ were relatively small at $9 \%, 15 \%, 8 \%, 16 \%, 13 \%$, and $8 \%$ for HW, CL, HW/CL ratio, head diameter, market maturity, and percentage of bolted plants, respectively. $\mathrm{G} \times \mathrm{E}$ variation for tipburn was the highest in this study at 33\% (Table 2).

The DREC environment (D313) was slightly positively correlated with D512 $(r=$ $0.42 ; P<0.01)$ and highly correlated with the rest of the environments (W313 $r=0.67$, W512 $r=0.64$, and S612 $r=0.62 ; P<0.01$ ) for HW; the same tendency was observed for yield-related traits, CL, HW/CL, head diameter, and market maturity. These significantly positive correlations suggest the presence of non-crossover $\mathrm{G} \times \mathrm{E}$ interactions due to the consistency from site to site for yield under warmer environments. Although significant, these correlations are not so high to disregard the presence of any crossover interaction that may hinder progress in selections for yield in warmer areas. Similar to crisphead lettuce, correlations among environments were positive and significant for yield in warmer environments for green and red leaf lettuce (Lafta et al., 2017) suggesting non-crossover interactions. The improvement of yield and its related traits in a warmer environment could be done using a mega-environment that represents the targeted area of a cultivar release. However, crossover interactions were found in physiological disorders that commonly appear as a consequence of growing lettuce under warmer conditions; for example, tip- burn, rib discoloration incidence, and ribbiness (Jenni and Hayes, 2010; Jenni and Yan, 2009). Although improvement of yield in warmer environments could be achieved using one mega-environment, precautions should be in place as physiological disorders may need multitrial, multiyear, multilocation evaluations because no consistent relationship was found among environments for tipburn and bolting in our study.

A different approach to understand $\mathrm{G} \times \mathrm{E}$ interaction is to graph (GGE biplot) singular value partitions using the which-won-where method that groups environment(s) into a mega-environment and identifying winning cultivar(s) for the specific target (mega) environment (Yan and Kang, 2002). The whichwon-where method of the Biplot is presented for each trait (Fig. 1). The average tester coordinate method was used to identify the most representative environment for each trait (Fig. 2). When cultivars were grouped in a GGE biplot, one mega-environment for
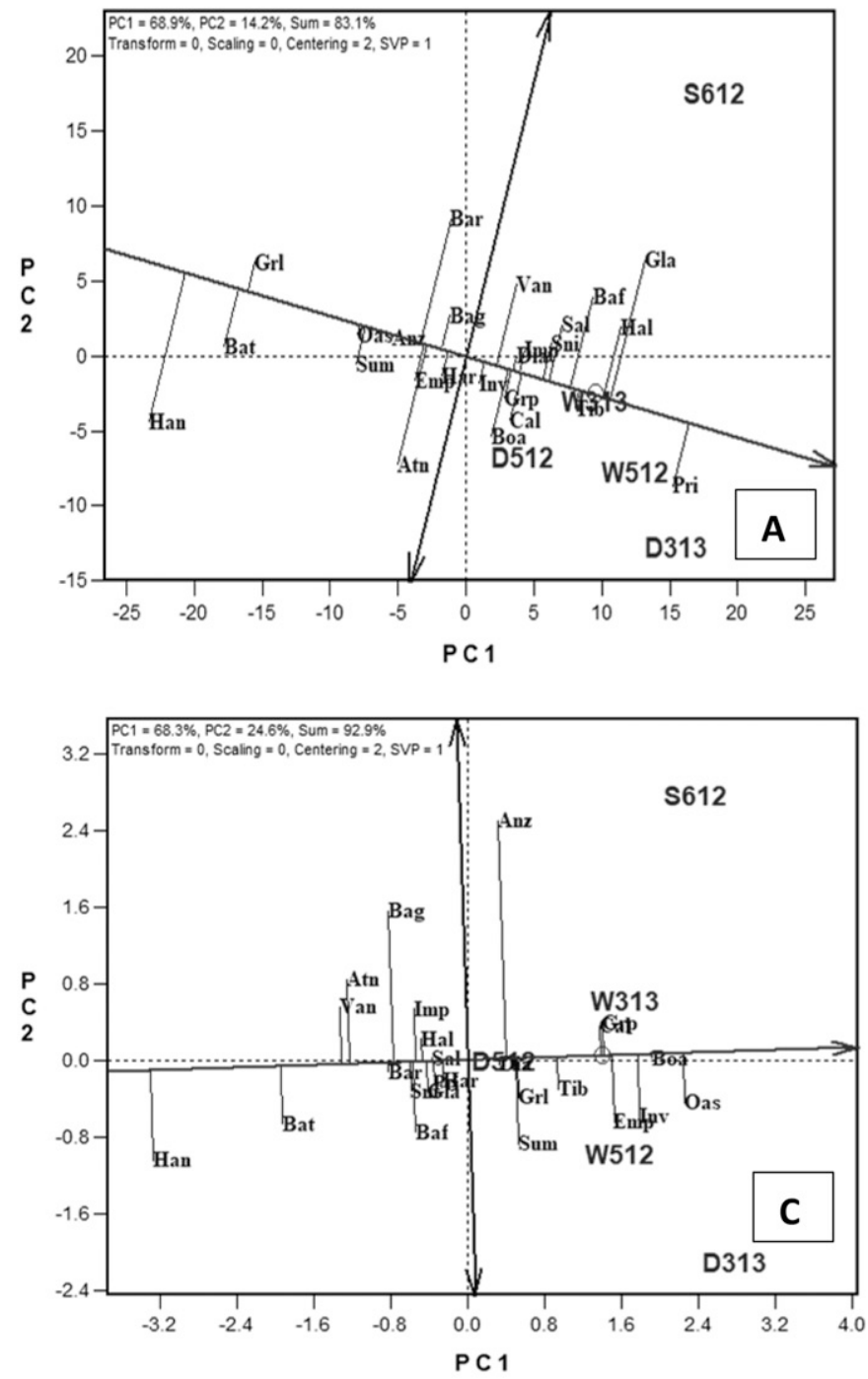

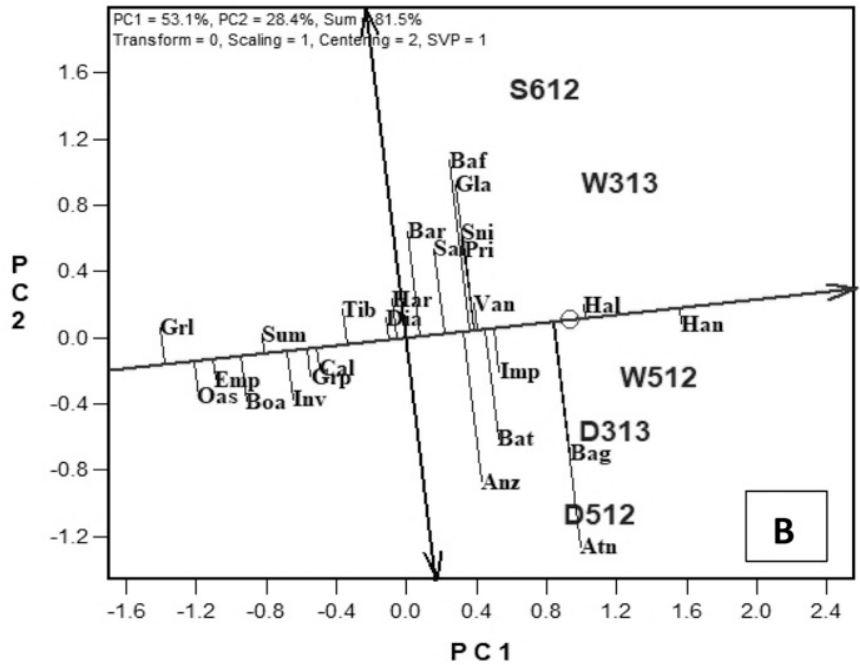

Which wins where or which is best for what

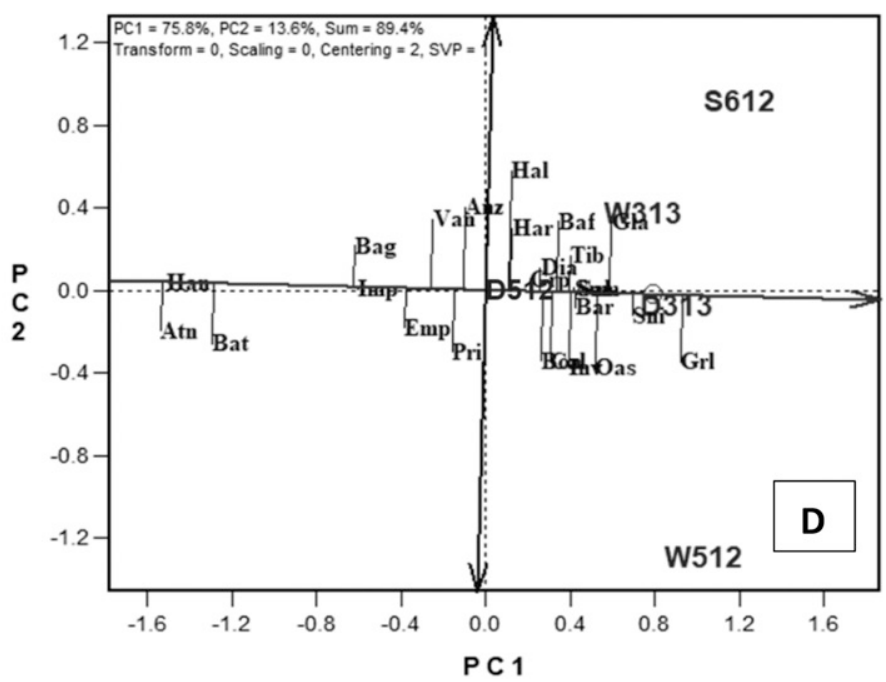

Fig. 2. The average environment coordination (AEC) of the GGE biplot showing the performance of crisphead lettuce genotypes for head weight (A), core length $(\mathbf{B})$, the head weight/core length ratio $(\mathbf{C})$, head diameter $(\mathbf{D})$, market maturity $(\mathbf{E})$, bolting $(\mathbf{F})$, and tipburn $(\mathbf{G})$. Environments are represented by D313 (Holtville, CA, March 2013 planting), D512 (Holtville, CA, May 2012 planting), W313 (Five Points, CA, March 2013 planting), W512 (Five Points, CA, May 2012 planting), and S612 (Salinas, CA, June 2012 planting). 
crisphead lettuce with higher HW is the Salinas June 2012 planting (S612), (Fig. 1A). In this environment, cultivar Glacier had the highest HW; other cultivars, such as Barrier Reef, Hallmark WS, Imperial 749, Salinas, Sniper, and Vanguard 75, had an acceptable HW. Nevertheless, this research was planned to find cultivars that could be planted in warmer environments. In the GGE biplot, DREC plantings in 2012 and 2013 (D512 and D313) and WSREC 2012 and 2013 plantings (W512 and W313) were grouped together in a second mega-environment for $\mathrm{HW}$ in warm environments. Cultivar Primetime had the highest HW in this mega-environment. The graphing of two mega-environments indicates that improvement for heat tolerance should be conducted under these warm environments and decision on selection should be based on mean performance and stability from experiments across several growing seasons, as previously described (Jenni and Hayes, 2010). Other yield-related traits, such as CL, HW/CL ratio, head diameter, and market maturity, also showed a similar grouping of these megaenvironments (Fig. 1B-E); a variety of differ- ent mega-environments in the GGE biplot (Fig. 1F and $\mathrm{G}$ ) were graphed for traits that are disorders (tipburn and bolting) due to heat. This is further proof for the existence of crossover $\mathrm{G} \times \mathrm{E}$ interactions for traits that are consequences of heat in crisphead lettuce.

The average environment coordination of the GGE biplot ranking showed that Tiber is the most stable cultivar across the five environments. 'Tiber' was the closest to the abscissa $x$ with little projection to the ordinate $y$ (Fig. 2A). In contrast, 'Glacier', 'Barrier Reef', and 'Vanguard 75' were the least stable cultivars across the five environments. The closest environment to the average in this research was WSREC Mar. 2013, as indicated by the small dotted circle in Fig. 2A. Although 'Primetime' was not the most stable in terms of performance, it produced the highest HW in warmer conditions and proved its value for breeding. Similarly, stability across environments was cultivar-dependent for each of the studied traits. For yield-related traits, Hallmark was the most stable cultivar for core length, 'Baomach' and 'Diamond' were the most stable for the HW/CL ratio, and 'Harvest Pride' was most stable for head diameter (Fig. 2B-D). 'Primetime' was the most stable across all environments tested for percentage of bolted plants and 'Anza' for the number of leaves with tipburn (Fig. 2F and $\mathrm{G}$ ).

Our data provided clear evidence of $\mathrm{G} \times \mathrm{E}$ interactions and environments are separated in warmer locations (Holtville and Five Points, CA) and a less warm location (the Salinas Valley in California in the summer planting in central California). Although a non-crossover $\mathrm{G} \times \mathrm{E}$ interaction was detected for HW, the negatively related traits, bolting and tipburn, exhibited differently across these environments, suggesting that breeding for heat tolerance should take into consideration these important characteristics during multilocation trials.

The Salinas Valley has a milder climate than Holtville and Five Points, meaning that selection for heat tolerance traits should be conducted in warmer conditions for lettuce. It is likely that the material improved for the central coastal California (e.g., the Salinas Valley) may not be immediately suitable for
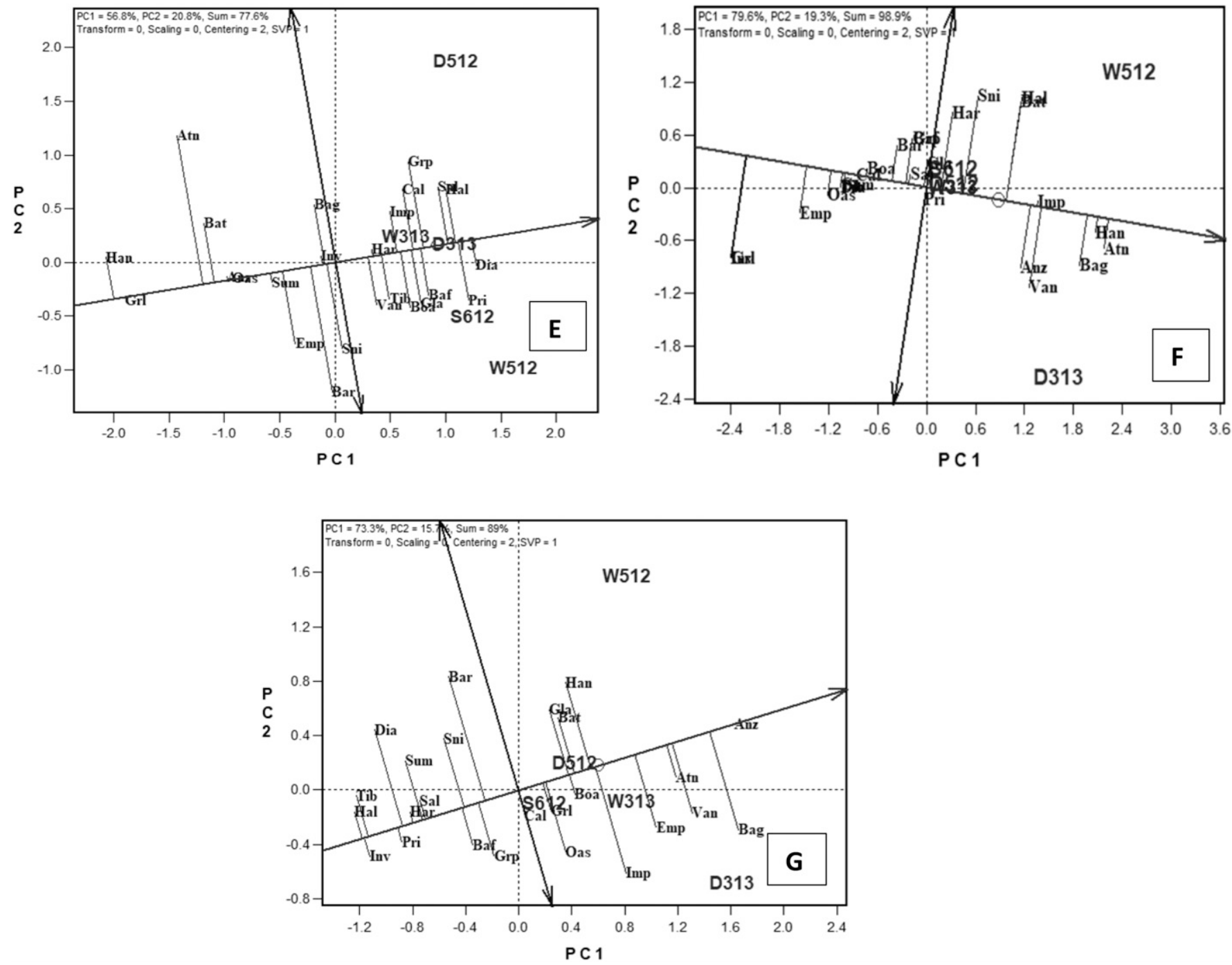

Fig. 2. (Continued) 
production in the warmer environments (i.e., San Joaquin and Imperial Valleys). Five Points Mar. 2013 may be an appropriate location with conditions that can improve lettuce for heat tolerance because it graphed near the ideal environment ( $x$ exe) when considering yield and other related traits, although for traits such as bolting, tipburn, and CL, the Five Points Mar. 2013 is graphed farther from the $x$ exe. Planting lettuce in March with harvest occurring until May could be adopted in warmer production areas.

Although the tested crisphead material presented genetic variability for HW and other physiological disorders as indicators of heat tolerance, there is room for improvement of crisphead lettuce to be adapted to warmer conditions. However, in this experiment, only a subset of available genotypes was tested in field conditions and there may be lettuce cultivars with higher heat tolerance that remain unidentified. Hence, additional tests of lettuce cultivars in different environments, especially lines that have been improved for bolting and tipburn, should be carried out. Breeding of heat-tolerant crisphead lettuce should be conducted in multitrial and multilocations because of the crossover interaction identified in physiological disorders that occur in part because of warmer environments.

\section{Literature Cited}

Ali, F., D.L.E. Waters, B. Ovenden, P. Bundock, C.A. Raymond, and T.J. Rose. 2019. Australian rice varieties vary in grain yield response to heat stress during reproductive and grain filling stages. J. Agron. Crop Sci. 205:179-187.

Barta, D.J. and T.W. Tibbitts. 2000. Calcium localization and tipburn development in lettuce leaves during early enlargement. J. Amer. Soc. Hort. Sci. 125:294-298.

Campbell, K. 2007. Agricultural land values increase. AgAlert, 2 May 2007. 7 Aug. 2020. $<\mathrm{http}: / /$ www.agalert.com/story/?id=813 $>$.

Chen, J., W. Xu, J. Velten, Z. Xin, and J. Stout. 2012. Characterization of maize inbred lines for drought and heat tolerance. J. Soil Water Conserv. 67:354-364.

Cox, E.F., J.M.T. McKee, and A.S. Dearman. 1976. The effect of growth rate on tipburn occurrence in lettuce. J. Hort. Sci. 51:297-309.

Driedonks, N., M. Wolters-Arts, H. Huber, G.-J. de Boer, W. Vriezen, C. Mariani, and I. Rieu. 2018. Exploring the natural variation for reproductive thermotolerance in wild tomato species. Euphytica 214:67.
FAOSTAT. 2018. Food and Agriculture Organization of the United Nations. 28 May 2020. $<$ http://www.fao.org/faostat/en/\#data/QC $>$.

Hayes, R.J. 2017. Lettuce breeding, p. 6-9. In: K.V. Subbarao, R.M. Davis, R.L. Gilbertson, R.N. Raid (eds.). Compendium of lettuce diseases and pests. 2nd ed. The American Phytopathological Society, St. Paul, MN.

Hayes, R.J., G. Sandoya, B. Mou, I. Simko, and K.V. Subbarao. 2018. Release of three iceberg lettuce populations with combined resistance to two soilborne diseases. HortScience 53:247250.

Holmes, S.C., D.E. Wells, J.M. Pickens, and J.M. Kemble. 2019. Selection of heat tolerant lettuce (Lactuca sativa L.) cultivars grown in deep water culture and their marketability. Horticulturae 5:50.

Jenni, S. 2005. Rib discoloration: A physiological disorder induced by heat stress in crisphead lettuce. HortScience 40:2031-2035.

Jenni, S. and R.J. Hayes. 2010. Genetic variation, genotype $\times$ environment interaction, and selection for tipburn resistance in lettuce in multienvironments. Euphytica 171:427-439.

Jenni, S. and W. Yan. 2009. Genotype by environment interactions of heat stress disorder resistance in crisphead lettuce. Plant Breed. 128: 374-380.

Karl, T.R. and K.E. Trenberth. 2003. Modern global climate change. Science 302:1719-1723.

Lafta, A., T. Turini, G.V. Sandoya, and B. Mou. 2017. Field evaluation of green and red leaf lettuce genotypes in the Imperial, San Joaquin, and Salinas Valleys of California for heat tolerance and extension of the growing seasons. HortScience 52:40-48.

Macias-González, M., M.J. Truco, L.D. Bertier, S. Jenni, I. Simko, R.J. Hayes, and R.W. Michelmore. 2019. Genetic architecture of tipburn resistance in lettuce. Theor. Appl. Genet. 132: 2209-2222.

Masarirambi, M.T., K.A. Nxumalo, P.J. Musi, and L.M. Rugube. 2018. Common physiological disorders of lettuce (Lactuca sativa) found in Swaziland: A review. Amer.-Eurasian J. Agr. Environ. Sci. 18:50-56. <https://hortintl.cals.ncsu. edu/articles/common-physiological-disorderslettuce-lactuca-sativa-found-swaziland-review>.

Mikel, M.A. 2007. Genealogy of contemporary North American lettuce. HortScience 42:489493.

Mikel, M.A. 2013. Genetic composition of contemporary proprietary U.S. lettuce (Lactuca sativa L.) cultivars. Genet. Resources Crop Evol. 60:89-96.

Ryder, E.J. 1979a. 'Salinas' lettuce. HortScience 14:283-284.

Ryder, E.J. 1979b. 'Vanguard 75' lettuce. HortScience 14:284-286.
Ryder, E. 1999. Lettuce, endive and chicory. CABI Publishing, New York.

Ryder, E., J.D. McCreight, and B. Mou. 2016. Vegetable cultivar descriptions for North America. Lettuce. 6 Aug. 2020. <https://cucurbit. info/vegetable-cultivar-descriptions-for-northamerica/>.

Ryder, E.J. and D.C. Milligan. 2005. Additional genes controlling flowering time in Lactuca sativa and $L$. serriola. J. Amer. Soc. Hort. Sci. 130:448-453.

Ryder, E.J. and W. Waycott. 1998. Crisphead lettuce resistant to tipburn: Cultivar Tiber and eight breeding lines. HortScience 33:903-904.

Sandoya, G.V., K. Subbarao, and R.J. Hayes. 2017. Delayed foliar symptoms caused by Verticillium dahliae as an alternative trait in iceberg lettuce. HortScience 52:513-519.

Silva, E.C., W.R. Maluf, N.R. Leal, and L.L.A Gomes. 1999. Inheritance of bolting tendency in lettuce Lactuca sativa L. Euphytica 109:1-7.

Simko, I., R.J. Hayes, B. Mou, and J.D. McCreight. 2014. Lettuce and spinach, p. 53-85. In: S. Smith, B. Diers, J. Spetch, and B. Carver (eds.). Yield gains in major U.S. field crops. ASA, CSSA, and SSSA, Madison, WI.

Thibodeau, O.P. and P.L. Minotti. 1969. The influence of calcium on the development of lettuce tipburn. J. Amer. Soc. Hort. Sci. 94:372-376.

Thompson, R.C. and E.J. Ryder. 1961. Descriptions and pedigrees of nine varieties of lettuce. U.S. Dept. Agric., Tech. Bul. No. 1244.

U.S. Department of Agriculture, National Agricultural Statistics Service (USDA-NASS). 2019. National Statistics for lettuce. 29 May 2020. $<$ https://quickstats.nass.usda.gov>.

Welch, J.E., R.G. Grogan, F.W. Zink, G.M. Kihara, and K.A. Kimble. 1965. Calmar: ...A new lettuce variety resistant to downy mildew. Calif. Agr. 19:3-4. <http://calag.ucanr.edu/Archive/? article $=$ ca.v019n08p3>.

Wurr, D.C.E., J.R. Fellows, and K. Phelps. 1996. Investigating trends in vegetable crop response to increasing temperature associated with climate change. Scientia Hort. 66:255-263.

Yan, W. 2001. GGEbiplot-A Windows application for graphical analysis of multienvironment trial data and other types of two-way data. Agron. J. 93:1111-1118.

Yan, W. and M.S. Kang. 2002. GGE biplot analysis: A graphical tool for breeders, geneticists, and agronomists. CRC Press, Boca Raton, FL.

Yan, W., M.S. Kang, B. Ma, S. Woods, and P.L. Cornelius. 2007. GGE biplot vs. AMMI analysis of genotype-by-environment data. Crop Sci. 47:643-653.

Yanagi, A.A., R.M. Bullock, and J.J. Cho. 1983. Factors involved in the development of tipburn in crisphead lettuce in Hawaii. J. Amer. Soc. Hort. Sci. 108:234-237. 